\title{
Measuring Course Competencies In A School Of Business: The Use Of Standardized Curriculum And Rubrics
}

\author{
Jane Whitney Gibson, Nova Southeastern University, USA
}

\begin{abstract}
This paper examines the growing emphasis on measurement of course competencies by individual college students through two course examples, an undergraduate course in managing change and conflict and a graduate course in human resource management. The author explains how standardized curriculum and assignment rubrics are being used to measure student achievement and as a vehicle for ongoing assurance of learning efforts.
\end{abstract}

Keywords: assurance of learning; rubrics; measuring course competencies

\section{INTRODUCTION}

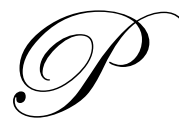

rogram goals, course competencies, learning objectives and standardized rubrics have long been a part of education, especially courses offered by Schools of Education where tools such as rubrics are regularly taught as part of the curriculum. Business schools, however, have been less likely to formalize standardized measurement of course competencies until fairly recently when the focus of accrediting bodies such as AACSB and the regional accreditors have shown increased concern about assessment of learning. Current AACSB standards, for example, require outcome-based assessment and direct assessment measures; these measures are recommended to be not just at the program level but to be embedded in courses (Kelley, Tong \& Choi, 2010; Weldy, Spake, \& Sneath, 2008). Documentation of student learning has thus become "increasingly important in decisions regarding initial accreditation and reaffirmation (by AACSB) (Hawkins, 2008, p. 2.) Post secondary educators are well aware that college offerings exist in a "climate of outcomes-based educational reform that has attained critical influence at all levels of U.S. education (Shaftel \& Shaftel, 2007, p. 215) and that "a close relationship exists between the appraisal of student achievement and the evaluation of educational programs, because measuring student outcomes may reveal the success or failure of educational programs" (Shaftel \& Shaftel, 2007, p. 217).

This paper uses evolving quality improvement initiatives at the H. Wayne Huizenga School of Business and Entrepreneurship at Nova Southeastern University (NSU) to illustrate how a comprehensive, unified approach to measuring course competencies can greatly assist in documenting accomplishment of program goals. Two course examples are used to suggest an approach to measuring course competencies through rubrics and standardized curriculum. We begin by looking at measuring competencies at the course level.

\section{MEASURING COMPETENCE AT THE COURSE LEVEL}

In a 2010 study of 420 deans at AACSB accredited business schools, researchers found that "minor modifications to existing courses and closer coordination of multisection courses were the most frequent changes made to improve student learning" (Kelley, Tong and Choi, 2010, p. 299). This coordination of multisection courses is at the heart of this current report. 
At NSU, a given course can be offered in four different formats: day, evening, weekend, and online. Additionally, the ground based courses can be offered on campus or at a distance around the State or even outside the country. While business courses have long used the same book and a "standard syllabus," it is well known that the variety of full time and adjunct faculty teaching the course demonstrate considerable variation in what they cover and what they require as student deliverables. In a broad-based effort to reduce this variation and to improve the consistency of our offerings and in conjunction with designing an enhanced assurance of learning program (AOL), the Huizenga School has begun an evolution to a Lead Professor Model where a full time faculty member designs a given course in such a way that it can be delivered with a team of Instructional Specialists. The Lead Professor is responsible for the standardized curriculum package including the rubrics by which all deliverables will be graded.

\section{Standardized Curriculum Packages}

One way of reducing the variation in what goes on in the classroom and thus the variation in student learning outcomes is by creating a standardized curriculum package which can be delivered through a team of qualified instructional facilitators. At NSU, the Lead Professor, in conjunction with other faculty who have been teaching the course, designs a curriculum package which consists of, among other things, a detailed syllabus, a series of content videos, instructions and rubrics for all deliverables, standardized tests, lesson plans for all formats, and an assurance of learning plan which directly measures all course competencies. The latter is documented through an end-of-term report during which the teaching team assesses outcomes and discusses continuous improvement measures.

A large part of the work of the Lead Professor is in designing rubrics for all course deliverables so that no matter who is doing the grading, the outcomes are much more likely to be similar.

\section{Use Of Grade Rubrics}

The National Institute for Learning Outcomes Assessment found in their 2009 report that faculty are "motivated to spend time creating rubrics because they know that rubrics will save them time in grading papers and in helping students understand the grading process. (p. 6)" This reduced time in grading, however, does come at considerable upfront cost since using rubrics does require "a great deal of thought and time when he/she composes and creates the project and its handout material for the first time (Amantea, 2004, p. 27). Advantages of using rubrics include not only reducing the amount of time it takes to grade assignments, but providing clear expectations to students, and the ability to consistently grade student work (Donathan \& Tymann, 2010, 477). While all of these points were critical to the current development process, the value of consistency is most important when a number of instructors are going to be grading the same assignment.

While the value of rubrics for improving student performance has been documented (Bolton, 2006; Suskie, 2004), students report the positive value of rubrics as establishing expectations, providing a guide for performance, identifying critical issues, and providing a vehicle for feedback (Bolton, 2006). But not everyone is in favor of rubrics. Some would argue that sharing rubrics with students will lead to "formulaic writing (Marcotte, p. 3)" although Marcotte suggests this is due to prescriptive as opposed to descriptive rubrics.

In spite of any lingering controversy over rubrics, the train has definitely left the station. In the study of AACSB deans referred to above, almost $92 \%$ of the deans said that written assignments graded with rubrics were a part of their assessment protocol. (Kelley, Tong, and Choi, 2010). This is not surprising given the AACSB requirement of direct, individual assessment since one good way to accomplish this is to "develop rubrics for presentations, writing assignments, and projects to facilitate standardized assessments (Weldy, Spake, \& Sneath, 2008, p. 18).

Another, less touted, benefit of rubrics is especially important for the Huizenga approach, namely that rubrics "open up communication among colleagues related to student learning" and "make assessment of student learning more objective." (Gort, Kieke, Moroz, \& Luebke, 2008, 116). This assessment directly feeds back into the close-the-loop features of the new process.

To more clearly explain the use of rubrics in the Lead Professor Model, the author uses examples from two courses she has developed 


\section{TWO COURSE EXAMPLES}

The author has been designated Lead Professor for an undergraduate management course, Managing Conflict and Change and a graduate HR course, Human Resource Management. Both courses are currently running in multiple formats in multiple locations and all instructors are using the rubrics designed by the author and approved through the internal AOL and Quality Review teams. These courses can provide examples of how rubrics are being used.

\section{Managing Conflict And Change}

HRM 3100 is an 8 week undergraduate class offered to management majors; however, it is a popular elective for other majors as well. Deliverables for the course include midterm and final exams, a book review, a selfassessment paper using the Thomas Kilmann Conflict Mode Instrument, and two reflection papers consisting of three short essays each. Students taking the course in the online format have exactly the same deliverables with the exception of the two reflection papers. The combined six questions of those papers are delivered through the weekly discussion question requirement for the online students. Whether answered as part of the reflection papers or as online discussion questions, the assignment is graded by the exact same rubric. These questions measure specific course competencies and thus results can be directly compared.

Here is an example. Reflection Paper One, Question One (Day, evening and weekend class formats) is identical to the Week One Discussion Question (online format) and states the following.

Use Lewin's 3 stages of change and describe an organizational change you have experienced (Either small-scale or large-scale change will do). If you are not working and have no organizational reference, interview someone you are close to about a change situation in their organization. Tell us about the unfreezing, introducing and refreezing steps of the change. How well did it work? What, if anything, could have been done better? (Course Competency \#1)

Regardless of format, here is the grade rubric used for this question.

Grade Rubric For Reflection Paper 1 - Question 1 (CC\#1)

\begin{tabular}{|l|l|l|l|l|}
\hline Criterion & $\begin{array}{l}\text { Does not meet basic } \\
\text { criterion }\end{array}$ & Meets basic criterion & Proficient & Outstanding \\
\hline $\begin{array}{l}\text { Applies Lewin's } \\
\text { theory to real-life } \\
\text { situation }\end{array}$ & $\begin{array}{l}\text { Does not demonstrate } \\
\text { knowledge of Lewin's } \\
3 \text { stages of change (0) }\end{array}$ & $\begin{array}{l}\text { Applies only one or } \\
\text { two of Lewin's 3 states } \\
\text { in specific terms (1) }\end{array}$ & $\begin{array}{l}\text { Applies 3 stages of } \\
\text { Lewin's theory to a } \\
\text { real-life change } \\
\text { situation (2) }\end{array}$ & $\begin{array}{l}\text { Gives robust examples } \\
\text { of Lewin's 3 stages } \\
\text { through the case } \\
\text { discussed (3) }\end{array}$ \\
\hline $\begin{array}{l}\text { Analyzes what went } \\
\text { well }\end{array}$ & $\begin{array}{l}\text { Does not analyze a } \\
\text { real-life situation using } \\
\text { Lewin's model (0) }\end{array}$ & $\begin{array}{l}\text { Describes what went } \\
\text { well in general terms } \\
(1)\end{array}$ & $\begin{array}{l}\text { Analyzes what went } \\
\text { well in each of the } \\
\text { three stages of change } \\
(2)\end{array}$ & $\begin{array}{l}\text { Gives specific } \\
\text { examples of what went } \\
\text { well throughout the } \\
\text { three stages (3) }\end{array}$ \\
\hline $\begin{array}{l}\text { Recommends what } \\
\text { could have been done } \\
\text { better }\end{array}$ & $\begin{array}{l}\text { Makes no } \\
\text { recommendations for } \\
\text { improvement in any of } \\
\text { the three stages of } \\
\text { change (0) }\end{array}$ & $\begin{array}{l}\text { Some evidence of } \\
\text { analytical ability in } \\
\text { recommending } \\
\text { improvements (1) }\end{array}$ & $\begin{array}{l}\text { Demonstrates clear } \\
\text { understanding of } \\
\text { change leadership } \\
\text { through } \\
\text { recommendations (2) }\end{array}$ & $\begin{array}{l}\text { Specifically addresses } \\
\text { improvements in two } \\
\text { or more stages of the } \\
\text { change situation (3) }\end{array}$ \\
\hline $\begin{array}{l}\text { Communicates in } \\
\text { clear, logical, } \\
\text { grammatically } \\
\text { correct terms }\end{array}$ & $\begin{array}{l}\text { Poorly written, } \\
\text { incoherent sentences, } \\
\text { poor spelling, } \\
\text { unacceptable grammar } \\
\text { (0) }\end{array}$ & $\begin{array}{l}\text { Numerous errors in } \\
\text { grammar, spelling, } \\
\text { punctuation, but } \\
\text { coherent, logical } \\
\text { discussion or vice } \\
\text { versa (1) }\end{array}$ & $\begin{array}{l}\text { Very few errors in } \\
\text { grammar, punctuation, } \\
\text { spelling. Coherent, } \\
\text { logical discussion (2) }\end{array}$ & $\begin{array}{l}\text { Virtually no errors in } \\
\text { grammar, punctuation, } \\
\text { spelling, completely } \\
\text { coherent and logical } \\
(3)\end{array}$ \\
\hline
\end{tabular}

Grade Equivalency: 0 points=0\%; 1 point $=20 \% ; 2$ points-40\%; 3 points $=60 \% ; 4$ points=70\%; 5/12=75\%; 6 points=80\%; 7 points $=82 \% ; 8$ points $=85 \% ; 9$ points $=88 \% ; 10$ points $=92 \% ; 11$ points $=96 \% ; 12$ points $=100 \%$ 
Several things should be pointed out about the effective use of rubrics in this and other courses

1. All rubrics are found in the syllabus so that students and faculty have easy access.

2. All deliverables (for all formats) are uploaded electronically to a course website using the Blackboard course management system.

3. Students are required to copy and paste corresponding rubric into their assignment before uploading

4. All rubrics and deliverables are visibly tied back to course competencies in a deliberate attempt to keep everyone's attention focused on the course competencies. In this case, the assignment relates to Course Competency \#1: Translate basic change management theories into organizational practices.

Similar to how this rubric is being used for this specific assignment, each of the other deliverables has its own rubric with the exception of the exams which are multiple choice exams housed on the Blackboard website and graded by the computer. If essay questions had been used, however, there would have been grade rubrics provided.

\section{Human Resource Management}

HRM 5030 is a 3 month, graduate level, 3 credit course taken by all management majors in the MBA program. Its deliverables also include a multiple choice midterm and final exam taken on the Blackboard course website as well as a team term paper, a team oral presentation of that paper (ground-based) or PPT presentation (online format), 8 current events assignments, and an individual case study. All of these deliverables are direct measures of course competencies, and in the case of team deliverables, there is also a corresponding individual assessment measurement.

One logistical difference in deliverables is that the case is submitted in one document by the ground-based students and in the form of two weekly discussion questions with the online groups. In the latter situation, the case study rubric is simply split into Part A and Part B for the online students. Similarly, current events are delivered each week in the online format but in two parts of 4 articles each in the weekend format. These differences are logistical only and the same grade rubrics apply. Here is what a current event rubric looks like. Note that it is submitted with each of the 8 current events.

Grade Rubric For EACH Current Event - (1 Point Each) Course Competency \#5

\begin{tabular}{|l|l|l|l|l|}
\hline Criterion & $\begin{array}{l}\text { Does not meet basic } \\
\text { criterion }\end{array}$ & Meets basic criterion & Proficient & Outstanding \\
\hline $\begin{array}{l}\text { Meets criterion of } \\
\text { "current event," i.e., } \\
\text { something happening } \\
\text { in the news right now } \\
\text { which is an actual } \\
\text { event and HR related }\end{array}$ & $\begin{array}{l}\text { Article chosen is } \\
\text { neither current nor an } \\
\text { event related to HR(0) }\end{array}$ & $\begin{array}{l}\text { Article is either } \\
\text { current OR an "event" } \\
\text { related to HR.(.1) }\end{array}$ & $\begin{array}{l}\text { Article is both current } \\
\text { and an "event" related } \\
\text { to HR (.15) }\end{array}$ & $\begin{array}{l}\text { Article is clearly a } \\
\text { significant current } \\
\text { event related to HR. } \\
(.2)\end{array}$ \\
\hline $\begin{array}{l}\text { Synthesizes and } \\
\text { reports key points of } \\
\text { the story }\end{array}$ & $\begin{array}{l}\text { Does not discuss key } \\
\text { points of the story }(0)\end{array}$ & $\begin{array}{l}\text { Provides broad } \\
\text { overview only of the } \\
\text { story. (.25) }\end{array}$ & $\begin{array}{l}\text { Gives some details of } \\
\text { story; reader may still } \\
\text { have questions }(.275)\end{array}$ & $\begin{array}{l}\text { Describes the essence } \\
\text { of the story answering } \\
\text { who, what, when, why, } \\
\text { and where }(.3)\end{array}$ \\
\hline $\begin{array}{l}\text { Explains the } \\
\text { relevancy of the story } \\
\text { to the HR profession }\end{array}$ & $\begin{array}{l}\text { No explanation given } \\
\text { of the relevancy of this } \\
\text { story. (0) }\end{array}$ & $\begin{array}{l}\text { Relates story to HR in } \\
\text { general terms }(.25)\end{array}$ & $\begin{array}{l}\text { Specifically relates } \\
\text { story to HR profession. } \\
(.275)\end{array}$ & $\begin{array}{l}\text { Fully explains } \\
\text { importance of the story } \\
\text { to HR theory and/or } \\
\text { practice }(.3)\end{array}$ \\
\hline $\begin{array}{l}\text { Communicates in } \\
\text { clear, logical, } \\
\text { grammatically } \\
\text { correct terms and } \\
\text { provides source in } \\
\text { APA style }\end{array}$ & $\begin{array}{l}\text { Poorly written, } \\
\text { incoherent sentences, } \\
\text { poor spelling, } \\
\text { unacceptable grammar } \\
\text { and/or total lack of } \\
\text { references, no citation } \\
(0)\end{array}$ & $\begin{array}{l}\text { Numerous writing } \\
\text { errors but sufficient, } \\
\text { appropriate and correct } \\
\text { references or vice } \\
\text { versa, citation present } \\
\text { but may be incomplete } \\
(.1)\end{array}$ & $\begin{array}{l}\text { Very few errors in } \\
\text { writing and referencing } \\
(.15)\end{array}$ & $\begin{array}{l}\text { Virtually no errors in } \\
\text { writing and } \\
\text { referencing. }\end{array}$ \\
\hline
\end{tabular}

Total points for EACH current event $=1$ 
Note that the current events assignment is (a) related directly to course competency \#5 (Demonstrate a familiarity with HR-related current events), and (b) worth an overall $1 \%$ of the student's grade. The "grader" just indicates the level of accomplishment on each criterion and adds up the total score.

Similar to the previous discussion of HRM 3100, all rubrics are found in the syllabus and students are required to copy and paste rubrics into their assignments before uploading to the course website. Instructors grade papers using these rubrics and return graded papers with comments through the Course Grade Center.

\section{CONCLUSION}

To date, the author has completed four cycles of HRM 5030 and is completing her third cycle of HRM 3100. The use of grade rubrics has been well accepted by Instructional Specialists working under the Lead Professor as well as the students involved. Anecdotal reports from students cite an increased comfort level with knowing exactly what is expected. Faculty find that students more accurately interpret the purpose and requirements of the assignments than before. A reinforcing part of this process is our determination that faculty provide concrete, timely feedback on all assignments and students clearly appreciate this. Stevens and Levi (2005) report that fast feedback is more useful and meaningful to students than is delayed feedback. Not only does it give them an idea of where they stand in the course, but it encourages them to self-correct on subsequent assignments.

The biggest benefit, programmatically, however, may be the considerable extra control it gives full time faculty over what is being taught in classes and a much better handle on how our course competencies are being met. No longer afraid we are comparing apples and oranges, we now have common assessments and measures to compare at the end of the term and to use in closing the all-important AOL loop.

\section{ABOUT THE AUTHOR}

Jane Whitney Gibson is a Professor of Management at the Wayne Huizenga School of Business and Entrepreneurship at Nova Southeastern University where she teaches undergraduate and graduate courses in management and leadership. Gibson is the Editor of The Journal of Applied Management and Entrepreneurship and the author of four books and many articles. Her current research interests are in the areas of online pedagogy, leadership, and generational values. Her most recent article, "Lillian McMurry of Trumpet Records: Integrity and Authenticity in the Charismatic, Constructive Narcissist Leader," appeared in the February 2011 issue of the Journal of Leadership \& Organizational Studies.

\section{REFERENCES}

1. Amantea, C. A. (2004) Using rubrics to create and evaluate student projects in a marketing course. Journal of College Teaching \& Learning, 1(4), 23-28.

2. Banta, T. W., Griffin, M., Flateby, T. L., \& Kahn, S. (December 2009). Three promising alternatives for assessing college students' knowledge and skills. National Institute for Learning Outcomes Assessment, Occasional Paper \#2. Retrieved February 12, 2011 from http://www.valenciacc.edu/instassess/CIA/documents/Banta.Griffin.Flateby.Kahnaritle.pdf

3. Bolton, F. C. (2006). Rubrics and adult learners: Andragogy and Assessment, 18(3), 5-6.

4. Donathan, K. \& Tymann, P. (2010). The development and use of scoring rubrics. Sigcse '10 Proceedings of the 41st ACM technical symposium on Computer science education. Retrieved February 12, 2011 from http://delivery.acm.org/10.1145/1740000/1734423/p477donathan.pdf?key1=1734423\&key2=2434257921\&coll=DL\&dl=ACM\&CFID=9711439\&CFTOKEN=346 $\underline{23308}$

5. Gort, A., Kieke, M., Moroz, K, \& Luebke, M. (2008). From isolated to collaborative: Assessing student learning using technology and rubrics. A Collection of Papers on Self-Study and Institutional Improvements, Volume 2, Chapter 4. Retrieved on February 12, 2011 from http://www.franciscan.edu/home2/Content/dean/PAPERS/Inovation\%20and\%20change/2114.pdf 
6. Hawkins, A. G. The assessment of business knowledge and integration for assurance of learning: An application. Journal of Case Studies in Accreditation and Assessment. Retrieved 2/12/2011 from http://www.aabri.com/manuscripts/10455.pdf

7. Kelly, C., Tong, P., and Choi, B-J. (2010). A review of assessment of student learning programs at AACSB schools: A dean's perspective. Journal of Education for Business, 85, 299-306.

8. Marcotte, M. (n.d.) Building a better mousetrap: The rubric debate. Viewpoints. Retrieved 2/12/2011 from http://faculty.ccp.edu/dept/viewpoints/w06v7n2/rubrics1.htm

9. Shaftel, J. \& Shaftel, T. L. (2007). Educational assessment and the AACSB. Issues in Accounting Education, 22(2), 215-232.

10. Stevens, D. (2005). Introduction to Rubrics. Sterling, VA: Stylus Publishing.

11. Suskie, I. (2004). Assessing Student Learning: A Common Sense Guide. Boston: Anker.

12. Weldy, T. G., Spake, D. F., \& Sneath, J. Z. (Fall 2008). Challenges and best practices: Meeting AACSB and SACS requirements. The Journal of Academic Administration in Higher Education, 4(2), 15-21 